\title{
BEZPIECZEŃSTWO POLSKI W OKRESIE ZIMNEJ WOJNY
}

Z II wojny światowej Polska wyszła poważnie osłabiona i poniosła olbrzymie straty. Zniszczony został majątek narodowy i mienie obywateli. Ludność zmniejszyła się z ok. 35 mln w 1939 r. do 22 mln w 1946 r. Liczbę bezpośrednich ofiar wojny szacowano na $6 \mathrm{mln}$.

Formujący się w grudniu 1944 r. z inspiracji Józefa Stalina Rząd Tymczasowy wskazywał, że Związek Radziecki zamierza w sposób trwały ugruntować swoje wpływy na obszarze zajętym przez Armię Czerwoną, a Polska Partia Robotnicza (PPR) - będąca fundamentem Rządu Tymczasowego będzie jego wiernym i oddanym sojusznikiem. Podzielony i skłócony polski rząd emigracyjny w Londynie kierowany przez socjalistę Tomasza Arciszewskiego stopniowo tracił na znaczeniu. Państwa zachodnie zachęcały go do ułożenia poprawnych stosunków ze Stalinem i wobec jego oporu, ograniczały swoje poparcie (Kersten, 1990).

Pomoc Związku Radzieckiego dla programu powrotu nad Odrę, uzyskania Szczecina i Gdańska w zamian za pogodzenie się z utratą kresów wschodnich II Rzeczypospolitej była zręcznym zabiegiem dyplomacji stalinowskiej (tzw. idea kompensacyjna). Przesunięcie granic Polski na zachód, jakkolwiek w dłuższej perspektywie okazało się zbawienne dla Polski, miało ją na trwale związać sojuszem z Moskwą. W społeczeństwie polskim starano się stworzyć wrażenie, że tylko rządy komunistycznej lewicy będą w stanie utrzymać i zagospodarować ,prastare” ziemie piastowskie. Argumentacja ta była prosta i klarowna. Ster władzy w ręku PPR i później Polskiej Zjednoczonej Partii Robotniczej to sojusz i przyjaźń ze Związkiem Radzieckim oraz jego gwarancje dla zachodniej granicy Polski. Obywatele odrzucający komunizm jawili się więc jako wrogowie polskiej racji stanu i podstawowych interesów państwa. Stalin był głęboko przeświadczony, że podobnie jak po I wojnie światowej, Niemcy w ciąu dwudziestu lat podźwigną się z upadku i upomną o utracone ziemie. Obecność Polski nad Odrą, Bałtykiem i Nysą Łużycką sprawiać miała permanentny stan napięcia i konfliktu z Niemcami, co gwarancjom radzieckim nadawało dodatkowego znaczenia (Koszel, 1996: 83-99).

Na mocy porozumień jałtańsko-poczdamskich państwa zachodnie zgodziły się na włączenie obszaru Europy Środkowej w orbitę wpływów radzieckich. Była to swoista forma wynagrodzenia ZSRR za olbrzymie ciężary poniesione na rzecz zwycięstwa nad III Rzeszą i Japonią. W tej sytuacji deklaracje J. Stalina o procesie demokratycznych reform na terenach okupowanych przez wojska radzieckie nie miały praktycznie żadnego znaczenia i służyły raczej uspokojeniu sumień polityków zachodnich. Metodą faktów dokonanych kreował on nową rzeczywistość, a opozycja w Polsce (Polskie Stronnictwo Ludowe) kierowana przez ludowego działacza Stanisława Mikołajczyka była zastraszana i systematycznie rozbijana (Paczkowski, 1993; Kersten, 1993). 
W miarę rozpadania się koalicji antyhitlerowskiej i powstania atmosfery zimnej wojny mocarstwa zachodnie definitywnie postawiły na odbudowę polityczna, gospodarczą i wojskową Niemiec Zachodnich. Kluczowe tutaj okazało się przemówienie amerykańskiego sekretarza stanu Jamesa Byrnesa wygłoszone w Stutgarcie 6 września 1946 r. Chcąc pozyskać Niemców do ewentualnej globalnej konfrontacji z komunizmem, uznał on granicę na Odrze i Nysie za tymczasową i nieprzesądzoną. Oznaczało to, że Stany Zjednoczone ostatecznie zrezygnowały z walki o Polskę. Dla S. Mikołajczyka i PSL, który szukał oparcia w mocarstwach zachodnich oznaczało to polityczną katastrofę i osobisty dramat. Propaganda PPR zręcznie to wykorzystała, sytuując opozycję w kręgu zdrajców narodu, którzy współpracując z USA, odrzucają żywotną dla interesów odradzającego się państwa granicę na Odrze i Nysie.

W latach 1945-1948 na obszarach kontrolowanych przez Związek Radziecki doszło do ustanowienia państw tzw. demokracji ludowej. Stalin głosił, że system kapitalistyczny znajduje się w stadium upadku, że jego miejsce zajmie ustrój socjalistyczny jako sprawiedliwszy i doskonalszy od kapitalizmu. Uważał, że w skali globalnej toczy się walka klasowa, która nieuchronnie doprowadzi do rewolucji społecznej i dyktatury proletariatu. Całą akcją propagandową i organizacyjną kierować i koordynować ją miało powstałe w 1947 r. Biuro Informacyjne Partii Komunistycznych i Robotniczych - Kominform (Borodziej, 1990).

Perspektywa stopniowego opanowywania dalszych części kontynentu europejskiego przez zaborczego Stalina zmusiła Stany Zjednoczone do przejęcia inicjatywy. 12 marca 1947 r. w Kongresie USA prezydent Harry Truman skrytykował ekspansywną politykę ZSRR i zapowiedział udzielenie pomocy finansowej państwom szczególnie narażonym na rozprzestrzenianie się wpływów komunistycznych (doktryna powstrzymywania). Jeżeli gwarancją polityczno-wojskowego zaangażowania się USA w Europie była doktryna Trumana, to jej filarem gospodarczym był plan Marshalla ogłoszony 5 czerwca $1947 \mathrm{r}$. Stany Zjednoczone wystapiły z propozycją udzielenia jednorazowej bezzwrotnej pożyczki w olbrzymiej wówczas wysokości (ostatecznie 13,5 mld dolarów) dla wszystkich państw europejskich, które poniosły straty wskutek agresji hitlerowskiej.

Od 27 czerwca do 2 lipca 1947 r. odbyła się w Paryżu konferencja ministrów spraw zagranicznych Wielkiej Brytanii, Francji i Związku Radzieckiego celem ustosunkowania się do Planu Marshalla. Minister spraw zagranicznych ZSRR Wiaczesław Mołotow uznał, iż ten plan jest raczej formą ratunku zagrożonej kryzysem gospodarki amerykańskiej. Państwa zniszczone wojną mogłyby z tej oferty skorzystać pod warunkiem jednak, że USA nie narzucałyby państwom - potencjalnym beneficjentom - warunków, które mogłyby ograniczyć ich suwerenność. Postulowane przez Marshalla, a popierane przez ministrów francuskiego i brytyjskiego plany powołania wspólnej europejskiej organizacji gospodarczej i ustalenie europejskiego planu odbudowy pod dyktando USA, miałyby w opinii W. Mołotowa godzić w niezawisłość poszczególnych państw. Efektem tego było odmówienie przez ZSRR przystapienia do takiej organizacji.

Z punktu widzenia Polski udział w planie Marshalla był pożądany, ponieważ mógł zapewnić dopływ kapitału, technologii i towarów dla zrujnowanej wojną gospodarki. Polskie władze początkowo zaakceptowały udział Rzeczypospolitej w amerykańskim planie pomocy gospodarczej, ale trwało to bardzo krótko. Już 9 lipca rząd polski kiero- 
wany przez Józefa Cyrankiewicza przekazał władzom USA notę, w której władze polskie odmówiły przyjęcia pomocy. Związek Radziecki, do którego Plan Marshalla był również adresowany, uznał to za „kapitalistyczną sztuczkę” i odmówił wzięcia w nim udziału.

Taką samą postawę władze w Moskwie narzuciły pozostałym państwom będących pod jej kontrola. W okresie od 16 do 22 września 1947 r. w Paryżu obradowali przedstawiciele 16 państw zdecydowanych do wzięcia udziału w planie Marshalla. Zgodnie z wcześniejszymi zapowiedziami w spotkaniu nie uczestniczyli delegaci ZSRR i pozostałych państw satelickich.

Zimna wojna, doktryna Trumana, która zaowocowała powstaniem Paktu Północnoatlantyckiego w 1949 r. i plan Marshalla, który stworzył podwaliny pod odbudowę gospodarczą Europy Zachodniej doprowadziły do konsolidacji państw zachodnich i powstania w 1951 r. pierwszej struktury integracyjnej na kontynencie Europejskiej Wspólnoty Węgla i Stali. Decydując się pod naciskiem Stalina na rezygnację z planu Marshalla i separując się pod przymusem od współpracy z Zachodem, Polska na blisko 40 lat odcięta została od wielkich zachodnioeuropejskich procesów integracyjnych i tym samym od cywilizacyjnego przyspieszenia (Koszel, 2007).

Tytułem pewnej rekompensaty i w odpowiedzi na tworzenie się pierwszych struktur integracyjnych w Europie Zachodniej było powołanie do życia przez J. Stalina podczas konferencji moskiewskiej z 5-8 stycznia 1949 r. Rady Wzajemnej Pomocy Gospodarczej. Formalnie rozpoczęła ona działalność 25 stycznia 1949 r, a w jej skład weszły państwa kontrolowane przez Związek Radziecki.

W latach 1948-1953 nastapiła kulminacja zimnej wojny w Europie i na świecie. W październiku 1949 r. dzięki pomocy ZSRR proklamowana została Chińska Republika Ludowa, co oznaczało rozszerzenie się wpływów komunistycznych na obszar Azji. W 1950 r. wybuchła wojna koreańska, w którą czynnie zaangażowały się USA i państwa zachodnie oraz CHRL i Związek Radziecki. W sierpniu 1949 r. Związek Radziecki wyprodukował własną bombę atomowa, co skłoniło Stalina do bardziej awanturniczych poczynań na arenie międzynarodowej (Czubiński, 1997: 279).

W Europie w 1948 r. doszło do zerwania współpracy zwycięskich mocarstw w sprawach niemieckich. We wrześniu 1949 r. proklamowano powstanie Republiki Federalnej Niemiec, a w odpowiedzi, w miesiąc później, Związek Radziecki doprowadził do utworzenia Niemieckiej Republiki Demokratycznej. Kontrolowane przez ZSRR drugie państwo niemieckie 6 lipca 1950 r. podpisało z Polską Układ o uznaniu granicy na Odrze i Nysie. Pomimo propagandowych zabiegów i zewnętrznie demonstrowanej solidarności obu państw na arenie międzynarodowej, stosunki PRL-NRD nacechowane były wzajemną podejrzliwością i brakiem zaufania (Skobelski, 2010).

System panujący w ZSRR sztucznie implementowano do innych państw demokracji ludowej, głosząc jego wyższość nad pozostałymi innymi. Wprowadzono gospodarkę planową i system monopartyjny. Pod hasłami obrony przez imperializmem mobilizowano społeczeństwa do nadzwyczajnej aktywności i atakowano „wrogów ludu”. W Polsce kierowanej przez oddanego J. Stalinowi Bolesława Bieruta represje dotknęły działaczy opozycyjnych, kadrę Wojska Polskiego oraz kapłanów i hierarchów Kościoła katolickiego. W gospodarce preferowano koncepcję rozbudowy przemysłu ciężkiego i forsowną industrializację kraju. Miało to doprowadzić do rozwoju potrzebnego 
w warunkach zimnej wojny przemysłu stalowego (zbrojeniowego) i poszerzyć liczbę robotników, potencjalnych członków PZPR. Plan sześcioletni (1950-1955) zakładał zwiększenie produkcji przemysłowej w 1955 r. o 85-95\% w stosunku do stanu z 1949 r. oraz zwiększenie produkcji rolnej o 35-45\%. Założenia te okazały się nierealistyczne, a koncepcja rozbudowy przemysłu ciężkiego według modelu radzieckiego do Polski nie pasowała. Technologie radzieckie były przestarzałe i energochłonne, wzrost produkcji przemysłowej odbywał się kosztem zaopatrzenia w żywność, odzież i inne artykuły pierwszej potrzeby (Czubiński, 1998: 290-291).

W marcu 1953 r. zmarł J. Stalin i na Kremlu rozpoczęła się walka o sukcesję, z której zwycięsko wyszedł niedoceniany przez przeciwników Nikita Chruszczow. Rozpoczęte zostały rozmowy z państwami zachodnimi, które doprowadzić miały do odprężenia w stosunkach międzynarodowych. Od 26 kwietnia do 20 lipca 1954 r. w Genewie odbyła się konferencja państw zachodnich i ZSRR, która została zwołana w celu znalezienia dróg do zjednoczenia Wietnamu i przedyskutowania warunków przywrócenia pokoju w Indochinach. Zakończyła się ona częściowym sukcesem i podziałem Wietnamu na dwa państwa. W Europie sytuacja przedstawiała się jednakże inaczej. Zgodnie z obietnicą USA w dniach 23-24 października 1954 r. w wyniku rokowań paryskich z udziałem państw zachodnich RFN uzyskała zgodę na remilitaryzację. 5 maja 1955 r. została oficjalnie przyjęta do NATO (Krasuski, 1987: 167).

W Polsce, gdzie powoli w kierownictwie PZPR nabrzmiewał konflikt pomiędzy zwolennikami utrzymania starego stalinowskiego porządku i działaczami domagającymi się destalinizacji i reform, kwestia remilitaryzacji Niemiec Zachodnich stała się doskonałym argumentem propagandowym na rzecz konsolidacji społeczeństwa wokół obozu komunistycznej władzy. Dobrze się orientowano, że przywoływanie tragicznych doświadczeń z okresu II wojny światowej i wskazywanie na rewizjonistów z RFN, gotowych do zbrojeń i kwestionowania granicy na Odrze i Nysie nadal trafia na podatny grunt $\mathrm{w}$ społeczeństwie. Nic więc dziwnego, że pozytywnie odniesiono się do powstania 14 maja 1955 r. w Warszawie sojuszu wojskowo-politycznego państw bloku wschodniego - Układu Warszawskiego (Koszel, 1999: 59-60).

Olbrzymie zmiany w ruchu komunistycznym i w relacjach na linii Wschód-Zachód przyniósł XX Zjazd Komunistycznej Partii Związku Radzieckiego. Na zamkniętym posiedzeniu Chruszczow ujawnił zbrodnie J. Stalina. Obiecał przywrócenie „leninowskiej praworządności" i wyraził zgodę na odrębne dochodzenie do socjalizmu przez państwa bloku wschodniego. Rozpoczęła się destalinizacja, ale proces ten w państwach kontrolowanych przez ZSRR przebiegał powoli, większe efekty odnotowano tylko na Wegrzech i w Polsce (Kemp-Welch, 2009).

W latach 1955-1956 w Polsce szala walki o władzę przechylała się na grupę reformatorską skupioną wokół Władysława Gomułki, represjonowanego wcześniej przez B. Bieruta. Zelżała cenzura i zatrzymano represje wobec Kościoła. Na mocy amnestii więzienia opuścili działacze opozycyjnego podziemia, przeorganizowane zostały cieszące się zbrodniczą sławą organy bezpieczeństwa, Polskę opuścili doradcy radzieccy kontrolujący armię i gospodarkę.

Po tzw. przełomie październikowym w $1956 \mathrm{r}$. w Polsce i objęciu władzy przez niechętnie początkowo przyjmowanego przez Kreml Gomułkę nie zmieniło się położenie międzynarodowe PRL. Uniknięto radzieckiej inwazji, jak to miało na Węgrzech w paź- 
dzierniku 1956 r. i wojska radzieckie maszerujące na Warszawę zostały zatrzymane. Polska jednak pozostała w radzieckiej strefie wpływów. Nowe kierownictwo partyjne gwarantowało Moskwie status quo na częściowo zmienionych zasadach, m.in. dzięki uzyskaniu większej samodzielności w stosunkach międzynarodowych. Polska zaczęła budować przyjazne relacje z wybranymi państwami zachodnimi - Francją i Wielką Brytanią. Zawarła umowę gospodarczą z USA i traktat handlowy z Japonią, reaktywowała stosunki z „wyklętą” przez J. Stalina Jugosławią. Spore zasługi na tym polu położył Adam Rapacki, który w kwietniu 1956 r. objął stanowisko ministra spraw zagranicznych (Liczmański, 1989).

Atmosfera odprężenia międzynarodowego, która zarysowała się po objęciu władzy na Kremlu przez N. Chruszczowa i zaproponowane przez prezydenta USA Dwighta Eisenhowera rozmowy rozbrojeniowe wywołały jednak zaniepokojenie w RFN, która pod rządami kanclerza K. Adenauera budowała swój prestiż i autorytet w obozie zachodnim przy pomocy zimnowojennej retoryki. Zachodnioniemiecka chadecja obawiała się, że odwilż w stosunkach pomiędzy supermocarstwami zagrozi prowadzonej przez nią ,„polityce z pozycji siły”, pogłębi podział Europy przez uznanie poczdamskiego ładu pokojowego i umniejszy znaczenie Republiki Federalnej w strefie wpływów Zachodu. Nie bez powodu determinantami bońskiej polityki zagranicznej było w tym okresie strategiczne założenie, że „zjednoczenie ma priorytet przed odprężeniem i rozbrojeniem" (Schwarz, 1983: 174; Bingen, 1997).

Wiosną $1957 \mathrm{r}$. po raz kolejny dyskutowano w Bonn na temat wyposażenia Bundeswehry w broń jądrową. Reakcją bloku wschodniego było zorganizowanie 9-11 maja 1957 r. w Berlinie Wschodnim konferencji przedstawicieli parlamentów Czechosłowacji, Polski i NRD, na której zaprotestowano przeciwko atomowym aspiracjom władz w Bonn. Dla Polski berlińskie spotkanie stworzyło możliwość skonsultowania z sojusznikami interesującego projektu, który narodził się w polskim MSZ - utworzenia strefy bezatomowej w Europie, znanego później jako plan Rapackiego. Według niektórych opinii ZSRR początkowo niechętnie odniósł się do tego pomysłu, uważając, że Plan Rapackiego mógłby naruszyć równowagę sił na niekorzyść Związku Radzieckiego i spowodować atak Zachodu, gdyż odczytany byłby jako przejaw słabości bloku wschodniego (Ozinga, 1989; Łoś, 2004: 119).

Kiedy w Moskwie zorientowano się, że nie będzie można liczyć na przychylność Niemiec Zachodnich wobec planu Rapackiego, to zmieniono stosunek wobec polskiej inicjatywy. Postanowiono wykorzystać ją propagandowo, tym bardziej, że plan Rapackiego mieścił się w ogólnych koncepcjach rozbrojeniowych Związku Radzieckiego, a cieszące się pewnym szacunkiem i autorytetem na Zachodzie nowe polskie kierownictwo mogło tylko dodawać wiarygodności tym propozycjom.

2 października 1957 r. na XII sesji Zgromadzenia Ogólnego ONZ minister Rapacki zgłosił oficjalnie projekt utworzenia w Europie Środkowej strefy wolnej od broni atomowej. Nawiązując do planów wyposażenia Bundeswehry w broń jądrową zadeklarował, że Polska zrezygnuje z produkowania i magazynowania na swoim terytorium arsenałów atomowych, jeżeli podobne zobowiązania podejmą dwa państwa niemieckie i Czechosłowacja. Użycie broni na tym obszarze miało być zakazane, miał również powstać odpowiedni aparat kontroli. Państwa socjalistyczne poparły ten projekt (Dokumenty, 1987, dok. 92: 164). 
Jak się należało spodziewać, Republika Federalna Niemiec odrzuciła plan Rapackiego. Kanclerz Adenauer uważał, że to nie tylko nie doprowadziłoby do wzmocnienia bezpieczeństwa Europy i Niemiec, lecz odcięłoby RFN od NATO i USA i byłoby pierwszym krokiem w kierunku neutralizacji RFN. Uznał, że Rapacki realizuje cele polityki radzieckiej, która zmierza do usunięcia Amerykanów z Europy i potwierdzenia status quo w Europie opartego na trwałym podziale Niemiec. Niezależnie od krytycznego stanowiska wobec kanclerza Socjaldemokratycznej Partii Niemiec (SPD), 23 stycznia 1958 r. Bundestag zaaprobował stanowisko szefa rządu (Kralewski, 1983: 61-72). Plan Rapackiego został ostatecznie pogrzebany w RFN z chwila, kiedy 25 marca 1958 r. Bundestag upoważnił kanclerza Adenauera i jego rząd do wyposażenia Bundeswehry w broń atomową i rakietową. Decyzja ta wywołała zmasowaną krytykę ze strony ZSRR i jej sojuszników, którzy oskarżyli RFN o chęć posiadania broni masowej zagłady. Teraz inicjatywę przejęła strona radziecka.

Pomimo porażki planu Rapackiego w stosunkach europejskich idea stworzenia stref bezatomowych na świecie znalazła uznanie, poparte konkretnymi działaniami. W 1961 r. Zgromadzenie Ogólne ONZ na wniosek Szwecji zaleciło stworzenie stref bezatomowych wszędzie tam, gdzie będzie to możliwe. Na wniosek władz Brazylii i Meksyku zaleciło denuklearyzację Ameryki Środkowej. W 1963 r. Finlandia złożyła wniosek o utworzenie strefy bezatomowej w Skandynawii (Łoś-Nowak, 1988).

Odprężenie w stosunkach na linii Wschód-Zachód, jakie nastąpiło po wizycie N. Chruszczowa w USA w 1959 r. zostało zagrożone w wyniku niespodziewanych wydarzeń, które miały miejsca w latach 1960-1962. W maju 1960 r. nad terytorium ZSRR zestrzelony został amerykański samolot szpiegowski $U$-2, a wzięty do niewoli pilot ujawnił kulisy wywiadowczej misji. 13 sierpnia $1961 \mathrm{r}$. rozpoczęto budowę muru berlińskiego, który na blisko trzydzieści lat podzielił obie części miasta. W październiku 1962 r. doszło do eskalacji konfliktu kubańskiego, który mógł zagrozić wywołaniem konfliktu nuklearnego o niewyobrażalnej skali.

Usunięcie radzieckich rakiet nuklearnych z terytorium Kuby i amerykańskich z obszaru Turcji spowodowało powrót od stołu rokowań. 25 lipca 1963 r. w Moskwie został parafowany układ pomiędzy ZSRR a USA i Wielką Brytanią o zaprzestaniu prób z bronią jądrową w atmosferze, przestrzeni kosmicznej i pod wodą. Polska podpisała to porozumienie 8 sierpnia 1963 r., uznając je za dobry krok na drodze do odprężenia i zarazem ponowienia polskiej inicjatywy (tj. planu Rapackiego) uwolnienia Europy Środkowej od broni masowej zagłady. Polski rząd chciał w ten sposób też zareagować na natowskie propozycje utworzenia wielostronnych nuklearnych sił w Europie z udziałem RFN i pogłębiający się nurt rewizjonistyczny w polityce Republiki Federalnej Niemiec.

28 grudnia 1963 r. na wiecu w Płocku W. Gomułka przedstawił oficjalnie kolejny plan rozbrojeniowy, który przewidywał zamrożenie istniejących zbrojeń na terenie RFN, NRD Czechosłowacji oraz PRL. W formie noty dyplomatycznej 29 lutego $1964 \mathrm{r}$. projekt kontrolowanej strefy zamrożenia zbrojeń w Europie przesłany został rządom Francji, USA, Wielkiej Brytanii, ZSRR, Czechosłowacji, Danii, Holandii, Belgii, NRD, RFN i Kanady (Zięba, 1989: 165; Małcużyński, 1965).

Plan Gomutki, podobnie jak poprzedni, został odrzucony przez Republikę Federalną Niemiec, która uznała go za kolejny manewr mający na celu osłabienie obronno- 
ści świata zachodniego przez obóz komunistyczny. Dopiero w trzy lata później, w tzw. nocie pokoju z 29 marca 1966 r. znanej jako inicjatywa pokojowa ówczesnego kanclerza RFN Ludwiga Erharda, władze w Bonn zaproponowały wschodnioeuropejskim sąsiadom swoją koncepcję - wyrzeczenia się siły w rozstrzyganiu spornych problemów międzynarodowych, ale pod pewnymi warunkami. Jednocześnie w nocie podtrzymano tezę o istnieniu Rzeszy Niemieckiej w granicach z 1937 r. oraz wskazywano, że dopiero po zjednoczeniu RFN i NRD ogólnoniemiecki suweren będzie uprawniony do uznania istniejących granic w Europie.

Usunięcie N. Chruszczowa ze stanowiska przywódcy KPZR w wyniku „puczu pałacowego" i zastapienie go przez Leonida Breżniewa w 1964 r. zbiegło się z rozpoczęciem interwencji amerykańskiej w Wietnamie, która po kryzysie berlińskim przesunęła punkt ciężkości zimnej wojny z Europy na Daleki Wschód.

W priorytetowo traktowanych przez Polskę relacjach z Republiką Federalną Niemiec następowały powolne i pożądane przez Warszawę zmiany. Po odejściu w $1963 \mathrm{r}$. K. Adenauera $z$ rządu problem rewizji granicy na Odrze i Nysie stopniowo tracił na znaczeniu. Następowała erozja doktryny Hallsteina, którą rząd „wielkiej koalicji” CDU/CSU-SPD (1966-1969) ostatecznie porzucił w 1967 r. W jej miejsce zaczęła funkcjonować koncepcja budowy „ładu pokojowego w Europie” propagowana przez SPD i późniejszego kanclerza Willy Brandta. Zakładała ona konieczność utrzymania status quo w Europie jako warunku późniejszego skutecznego oddziaływania na jego zmianę w sposób pokojowy, za zgodą wszystkich zainteresowanych stron.

Bońska koncepcja „ładu pokojowego” autorstwa SPD dobrze wpisywała się w ogłoszoną 14 grudnia 1967 r. w tzw. raporcie Harmela nową strategię NATO, zakładającą utrzymanie wspólnej obrony opartej na odstraszaniu i jednoczesnym dialogu politycznym ze Wschodem. Niezwykle istotnym elementem tej strategii było uznanie priorytetu odprężenia w stosunkach Wschód-Zachód przed zjednoczeniem Niemiec. Nowe tony w polityce wschodniej rządu Kurta Georga Kiesingera wzbudzały nieufność W. Gomułki, ale też zmuszały obóz socjalistyczny do określenia swojego stanowiska (Tomala, 1987: 259-260).

Po uzyskaniu wsparcia partii komunistycznych i robotniczych w Europie zebranych na konferencji w Karlowych Warach w 1966 r. oraz sojuszników z Układu Warszawskiego, wyrażonego w Apelu budapeszteńskim, państwa bloku wschodniego w 1969 r. przedstawiły warunki wstępne procesu odprężeniowego w Europie, którego szczytowym momentem miała być Konferencja Bezpieczeństwa $i$ Wspótpracy $w$ Europie (KBWE). Wśród tych warunków mieściły się także polskie postulaty sformułowane przez W. Gomułkę - uznanie ostateczności i nienaruszalności wszystkich istniejących granic w Europie, w tym polskiej granicy państwowej na Odrze i Nysie, prawnomiędzynarodowe uznanie NRD i rezygnacja RFN z dążenia do posiadania broni jądrowej, włącznie z przystąpieniem do układu o nieproliferacji (Gomułka, 1984: 364).

Nadzieje na szybki postęp w procesie odprężenia na linii Wschód-Zachód okazały się przedwczesne. Jedynym jasnym punktem w nowych uwarunkowaniach międzynarodowych był podpisany w Moskwie, Londynie i Waszyngtonie 1 lipca 1968 r. Układ o nierozprzestrzenianiu broni jądrowej, który tego samego dnia został przyjęty przez Polskę. Jednakże, po objęciu stanowiska prezydenta USA w 1968 r., Richard Nixon próbował wciagnąć Chińską Republikę Ludową do globalnej gry przeciwko Związko- 
wi Radzieckiemu, również w wojnie w Wietnamie na ówczesnym etapie nie widać było szans na pokojowe rozwiązania. Ale prawdziwym problem dla bloku wschodniego okazała się ,,praska wiosna” i objęcie władzy przez Aleksandra Dubčeka. Dla I sekretarza KC KPZR Leonida Breżniewa praskie liberalne reformy miały charakter kontrrewolucji, której natychmiast należało zapobiec. Duże naciski na jej stłumienie wywierali także W. Gomułka oraz W. Ulbricht, którzy obawiali się, że po wyjściu Czechosłowacji z Układu Warszawskiego RFN może zakwestionować powojenny układ granic. 20 sierpnia 1968 r. doszło do interwencji państw Układu Warszawskiego przy udziale żołnierzy Związku Radzieckiego, Bułgarii, NRD, Węgier i Polski. Reformy zostały brutalnie stłumione, a doktryna Breżniewa zakładająca ograniczoną suwerenność państw socjalistycznych święciła tryumfy (Eisler, 2008).

W 1968 r. w wyniku „wydarzeń marcowych” i rozpętania w Polsce antysemickiej nagonki, trudnej sytuacji gospodarczej, udziału w interwencji w Czechosłowacji osłabła pozycja W. Gomułki, którego przywództwo zaczęło być coraz częściej podważane i kwestionowane. Jego polityczną obsesją stało się wówczas doprowadzenie do uznania przez RFN polskiej granicy na Odrze i Nysie oraz uznania suwerenności państwowej NRD i tutaj można było odnotować poważny sukces. Utworzenie jesienią rządu socjalliberalnego (SPD-FDP) pod kierownictwem Willy'ego Brandta przyniosło przełom w zachodnioniemieckiej polityce wschodniej i otwarcie się RFN na odprężenie poprzez regulację stosunków z państwami socjalistycznymi z uwzględnieniem spornych problemów wynikających z następstw II wojny światowej. Po długich negocjacjach 7 grudnia 1970 r. w Warszawie doszło do podpisania pomiędzy PRL i RFN układu normalizacyjnego. Art. I układu poświęcony uznaniu przez RFN zachodniej granicy państwowej Polski został tak sformułowany, aby uszanować pozycje prawne obu stron. Podpisanie układu grudniowego W. Gomułka uznał za ukoronowanie swojej polityki zagranicznej (Koszel, 2007: 230).

„Zmiana warty” nad Renem w 1969 r. oznaczała przewartościowanie dotychczasowych priorytetów w polityce wschodniej i generalnie europejskiej RFN. W praktyce oznaczało to erozję klimatu zimnej wojny w Europie, gdyż Bonn zaangażowało się poważnie we współpracę pomiędzy dwoma blokami w celu wzmocnienia poziomu bezpieczeństwa europejskiego. Celem miało być stworzenie sprzyjającego klimatu dla nowej niemieckiej koncepcji pokojowego porządku w Europie, którego ważnym elementem była „zmiana przez zbliżenie” (niem. Wandel durch Annäherung), czyli - jak to słusznie odczytywano w Polsce - pokojowego ,wyłuskiwania” NRD z obozu państw socjalistycznych i doprowadzenie do zjednoczenia Niemiec inną drogą $\mathrm{i}$ innymi metodami.

Międzynarodowa pozycja RFN wzrosła na początku lat siedemdziesiątych po otrzymaniu przez W. Brandta Pokojowej Nagrody Nobla. Wykorzystując tę sprzyjającą atmosferę i dążenie obu supermocarstw do kontynuacji dialogu odprężeniowego po zakończeniu wojny w Wietnamie (1972), Republika Federalna wsparła koncepcję zwołania Konferencji Bezpieczeństwa i Współpracy w Europie, do której rozpoczęto przygotowania w $1973 \mathrm{r}$. Przyjęcie obu państw niemieckich do ONZ ostatecznie usankcjonowało pozycję RFN jako państwa, którego odprężeniowa polityka przyniosła Europie stabilizację polityczna. Opinia światowa uznała, że podpisując układy wschodnie RFN wykazała dużo dobrej woli oraz, że w tym kraju głęboko zakorzeniły się tendencje pokojowe i odprężeniowe. 
Dramatyczne i krwawe wydarzenia w grudniu 1970 r. na Wybrzeżu odsunęły W. Gomułkę od władzy i pozwoliły na przejęcie steru rządów przez nową ekipę funkcjonariuszy PZPR z Edwardem Gierkiem na czele. Nowy I Sekretarz KC PZPR przez 23 lata przebywał na emigracji w Europie Zachodniej i nie posiadał antyzachodnich, a przede wszystkim antyniemieckich uprzedzeń. Nowe kierownictwo partyjne było świadome zastoju cywilizacyjnego Polski, odziedziczonego w spadku po W. Gomułce, i konieczności wyjścia z tego impasu i szerszego otwarcia Polski na świat. Powoli, przy wielkich oporach starych struktur do głosu zaczęli dochodzić partyjni technokraci zafascynowani zachodnim stylem życia i zarządzania gospodarką, stawiający na dalszym planie pryncypia ideowe (Gajdziński, 2014).

Ekipa E. Gierka, podobnie jak wcześniejsza W. Gomułki w kontaktach z państwami zachodnimi miała ograniczone możliwości prowadzenia własnej polityki. Było to uwarunkowane przynależnością PRL do Układu Warszawskiego i RWPG. Najważniejsze decyzje, te o znaczeniu globalnym i strategicznym zapadały nadal w Moskwie, a doktryna Breżniewa, skutecznie wyegzekwowana w 1968 r. w Czechosłowacji odstraszała niepokornych i uświadamiała, że próby eksponowania własnej niezależności skazane są na niepowodzenie.

W świetle tej konstatacji nie mogły dziwić słowa, które padły z ust E. Gierka podczas jego pierwszej podróży zagranicznej po objęciu władzy, skierowane do gospodarzy na Kremlu 5 stycznia 1971 r. Przywódca PZPR silnie podkreślił, że miejsce polityki zagranicznej PRL jest „w ramach polityki globalnej ZSRR” (Gierek i Jaroszewicz, 1991). Ta czołobitna deklaracja opłaciła się, ponieważ L. Breżniew darzący Gierka osobistą sympatią zezwolił Polsce na nawiązanie bliższych kontaktów, zwłaszcza o charakterze gospodarczym, z państwami zachodnimi.

Wykorzystując atmosferę międzynarodowego odprężenia, czego dowodem były prowadzone w klimacie wzajemnego zaufania rozmowy przygotowawcze do KBWE, E. Gierek i jego ekipa postawili na wielostronną kooperację z państwami zachodnimi, która miała przyspieszyć modernizację Polski. Korzystając z nisko wówczas oprocentowanych kredytów Polska zaciągała zagraniczne pożyczki. Kupowano licencje i nowoczesne linie technologiczne. Szczególnie bliskie relacje łączyły E. Gierka z kanclerzem RFN Helmutem Schmidtem i prezydentem Francji Válery'm Giscardem d'Estaing. Wprowadzono ułatwienia paszportowe, dzięki czemu Polacy w przeciwieństwie do innych państw socjalistycznych mogli podróżować na Zachód (Rolicki, 1990).

Przyjęcie Aktu Końcowego KBWE w początkach sierpnia 1975 r. było szczytowym momentem odprężenia w stosunkach międzynarodowych lat siedemdziesiątych. Polskie kierownictwo partyjno-państwowe potraktowało to jako otwarcie nowego etapu we współpracy gospodarczej i politycznej z Zachodem, głównie z RFN i Francją.

Jeszcze nie minęła euforia związana z KBWE w stolicy Finlandii, a już barometr stosunków międzynarodowych zaczął iść w dół. ZSRR i USA rozpoczęły stopniowy odwrót od odprężenia. Polityka Kremla zmierzała do uzyskania przewagi wojskowej nad Stanami Zjednoczonymi i NATO, którą wywołało rozmieszczenie rakiet atomowych średniego zasięgu SS-20 na terytorium zachodnich rubieży ZSRR, a następnie w NRD oraz Czechosłowacji. W tym okresie były to najnowocześniejsze rakiety na świecie. Dzięki ich szybkości i zwłaszcza precyzji razić mogły dowolne cele położone 
w Europie Zachodniej. Jednocześnie władze ZSRR zaczęły naciskać na „bratnie” kraje socjalistyczne, aby nie wiązały się zbytnio z państwami zachodnimi.

Zaostrzyła się sytuacja międzynarodowa. 11-12 grudnia 1979 r. zapadła w Brukseli tzw. podwójna decyzja NATO, zapowiadająca rozmieszczenie w Europie Zachodniej amerykańskich rakiet średniego zasięgu (Pershing II i Cruise). 27 grudnia 1979 r. Związek Radziecki rozpoczął interwencję w Afganistanie, co szybko doprowadziło do przywrócenia klimatu zimnej wojny w stosunkach pomiędzy blokiem wschodnim i państwami Sojuszu Północnoatlantyckiego.

Niekorzystny zwrot w sytuacji międzynarodowej był dla ekipy Edwarda Gierka prawdziwą katastrofą. Zawiodły próby modernizacji kraju oparte o zachodnie kredyty i licencje. Od czasu wojny izraelsko-arabskiej w 1973 r. (tzw. Yom Kippur) i drastycznych podwyżek cen ropy naftowej na rynkach finansowych świata panowała niepewność i nerwowość. Wzrosło oprocentowanie kredytów, ich pozyskiwanie stało się coraz trudniejsze. Jeżeli udało się otrzymać kredyty to na gorszych warunkach i z krótszym terminem spłaty. Polska stopniowo wpadała w pułapkę zadłużenia, półki sklepowe pustoszały. W $1976 \mathrm{r}$. protesty społeczne spowodowały zamieszki i wywołały demonstracje uliczne w Ursusie i Radomiu. Interweniowała milicja, wiele osób zostało zatrzymanych i poddanych represji. Jesienią 1976 r. powstał Komitet Obrony Robotników, skupiający opozycyjnych działaczy, biorący w obronę represjonowanych robotników, nagłaśniający w zachodnich środkach masowego przekazu przypadki łamania praw człowieka (Skórzyński, 2012).

Wizerunek Polski jako stosunkowo liberalnego kraju w bloku wschodnim został poważnie nadwyrężony. Już w lutym 1976 r. pod naciskiem władz w Moskwie do Konstytucji PRL został wprowadzony zapis, że Polska nie jest już krajem „demokracji ludowej”, lecz jest państwem „socjalistycznym”, a w swojej polityce umacnia przyjaźń ze Związkiem Radzieckim i innymi państwami socjalistycznymi. Budziło to społeczny opór, który został wzmocniony wyborem Polaka kardynała Karola Wojtyły na papieża w październiku $1978 \mathrm{r}$.

Polska Ludowa stała się obiektem powszechnej krytyki ze strony zachodnich mass mediów (Radio Wolna Europa). USA w porozumieniu ze Stolicą Apostolską i papieżem Janem Pawłem II oskarżały ekipę E. Gierka, że nie realizuje podpisanych w 1975 r. w Helsinkach zobowiązań w sprawie współpracy w zakresie ochrony praw człowieka, sugerowano zerwanie współpracy z ZSRR i całym blokiem wschodnim (Czubiński, 1997: 359).

Protesty robotnicze w Polsce w 1980 r., narodziny „Solidarności” stworzyły realne zagrożenie dla utrzymania przez Kreml pod kuratelą Polski, uważanej za najsłabsze ogniwo bloku wschodniego. Po odsunięciu E. Gierka od władzy, liczono, że przejęcie w początkach $1981 \mathrm{r}$. stanowiska premiera i szefa partii przez generała Wojciecha Jaruzelskiego powoli na utrzymanie pod osłoną wojska kontroli nad rozwojem sytuacji. Jednocześnie wzmogły się naciski radzieckie i otwarte żądania pod adresem nowych władz o wyeliminowanie antysocjalistycznych, radykalnych elementów z życia publicznego i zdławienie „Solidarności” siłą.

Nie ulega wątpliwości, że z punktu widzenia Stanów Zjednoczonych i prowadzonej przez nich globalnej polityki wobec obozu komunistycznego, zryw wolnościowy w Polsce był dla administracji Ronalda Reagana wyjątkowo na rękę. Zaangażowanemu 
w Afganistanie Związkowi Radzieckiemu przybył nowy problem, co dodatkowo osłabiało radzieckie imperium (Mac Eachin, 2002). Amerykanie grożąc sankcjami ekonomicznymi przestrzegali przed siłowym rozwiązaniem konfliktu i radziecką interwencją zbrojną. Podobne stanowisko zajmowały czołowe państwa europejskie z Wielką Brytanią, Francją i RFN na czele.

13 grudnia generał W. Jaruzelski pod naciskiem ZSRR ogłosił wprowadzenie stanu wojennego w Polsce, mając świadomość negatywnych reperkusji międzynarodowych. W odwecie państwa zachodnie wprowadziły sankcje ekonomiczne wobec Polski i Związku Radzieckiego oraz odcięły Polskę od linii kredytowych i zagranicznych pożyczek. Polska została izolowana w Europie, a jej międzynarodowy autorytet spadł praktycznie do zera. Liczyć mogła wyłącznie na ekonomiczną pomoc ze strony ZSRR, co powodowało z kolei jeszcze większe uzależnienie od wschodniego sąsiada. W innych państwach tzw. demokracji ludowej, a w szczególności w NRD otwarcie krytykowano zbyt miękką postawę władz wobec solidarnościowej opozycji.

Szczególnie niekorzystne przemiany nastapiły w Republice Federalnej Niemiec. Niemcy Zachodnie pod rządami socjaldemokratów i liberałów wstrzemięźliwie odnieśli się do wprowadzenia stanu wojennego w Polsce, chcąc ratować resztki odprężenia międzynarodowego i utrzymać budowaną wielkimi kosztami politykę zbliżenia do drugiego państwa niemieckiego - NRD. W Warszawie było to odpowiednio doceniane. Rewizjonizm zachodnioniemiecki będący stałym elementem propagandy w Polsce Ludowej zniknął ze środków masowego przekazu. Wrogiem publicznym numer jeden w PRL stały się Stany Zjednoczone i osobiście prezydent Ronald Reagan. W 1982 r. obiektem stałych ataków generała Jaruzelskiego z trybuny sejmowej, czy na plenach PZPR (VIII i IX) była administracja amerykańska, podczas gdy inne kraje krytykujące stan wojenny określane były ogólnikowo „państwami kapitalistycznymi” lub „imperialistycznymi” (Koszel, 1992: 192-193).

Po rozpadzie koalicji rządowej w RFN we wrześniu 1982 r. i utworzeniu nowej koalicji CDU/CSU-FDP z kanclerzem Helmutem Kohlem na czele, nowy rząd federalny w większym stopniu zaczął się solidaryzować z polityką amerykańską wobec całego bloku radzieckiego. Spowodowało to odrodzenie się nurtu rewizjonistycznego w RFN, wzrostu aktywności Związku Wypędzonych, dotąd skutecznie powściąganych przez socjaldemokratów i liberałów. Począwszy od 1983 r. na terytorium RFN, ale także Włoch i Wielkiej Brytanii rozpoczęto instalację amerykańskich atomowych rakiet średniego zasięgu, co dodatkowo potęgowało napięcie w relacjach Wschód-Zachód (Góralski, Barcz, 1987).

Stany Zjednoczone pod rządami R. Reagana narzuciły nowy wyścig zbrojeń, podejmując różne inicjatywy (m.in. broń neutronowa, Inicjatywa Obrony Strategicznej - SDI, globalny systemy obrony przeciwrakietowej $B M D$ ).Wychodzono z założenia, że Związek Radziecki nie będzie w stanie pod względem ekonomicznym sprostać amerykańskim wyzwaniom i dojdzie do rozkładu, albo przynajmniej do poważnego osłabienia sowieckiego imperium. Wystarczy powiedzieć, że w 1988 r. Stany Zjednoczone na zbrojenia wydały około 300 mld dolarów, a Związek Radziecki był w stanie wysupłać tylko 145 mld dolarów (Karwat, 2007: 205).

Po zniesieniu stanu wojennego w 1983 r. sytuacja w Polsce nie mogła powrócić do stanu sprzed $1980 \mathrm{r}$. Wewnętrzne napięcia były zbyt silne, pogłębiał się podział na obóz 
władzy i ludzi związanych z solidarnościową opozycją. Opór przeciwko władzy powodował systematyczne pogarszanie się sytuacji ekonomicznej i dramatyczny wzrost procesów inflacyjnych. Do 1989 r. Polska znajdowała się w stanie zapaści ekonomicznej.

Trudno było w zaistniałej sytuacji mówić o wzroście znaczenia PRL w polityce międzynarodowej i jej wpływie na relacje z jej najbliższym otoczeniem. Szczególny niepokój budziły polepszające się kontakty pomiędzy Bonn i Berlinem Wschodnim, o czym polska dyplomacja nie była informowana, a często przez stronę wschodnioniemiecką po prostu ignorowana. Było to nie do pomyślenia w latach sześćdziesiątych i siedemdziesiatych.

Nieprzypadkowo w latach 1984-1985 pojawiły postulaty rządu RFN domagającego się ,przezwyciężenia podziału Europy i podziału Niemiec” i obalenia tego głównego reliktu „zimnej wojny”. Obserwując podtrzymywanie przez rząd H. Kohla polityki zbliżenia do NRD, Polska obawiała się realizacji zjednoczenia Niemiec, którego pierwszym etapem miało być utworzenie „Konfederacji Niemieckiej” (Rotfeld, 1984: 51-53).

Zbliżenie pomiędzy Berlinem Wschodnim i Bonn zaowocowało wspólną inicjatywą SPD i Socjalistycznej Partii jedności Niemiec (SED) w sprawie utworzenia w Europie strefy wolnej od broni chemicznej W marcu 1984 r. odpowiednie porozumienie w tej kwestii podpisali przewodniczący frakcji parlamentarnej SPD Hans-Jochen Vogel i przywódca NRD Erich Honecker. Plan przedstawiony 19 czerwca na międzynarodowej konferencji prasowej miał uwolnić od broni chemicznej w pierwszej kolejności terytorium RFN, NRD i Czechosłowacji, a następnie Polskę, kraje Beneluksu i Wielką Brytanię (Thiem, 1989: 107-113).

Objęcie w marcu 1985 r. stanowiska Sekretarza Generalnego KPZR przez Michaiła Gorbaczowa doprowadziło do stopniowej erozji nurtu zimnowojennego w polityce ZSRR i USA. Podjęte zostały bezpośrednie rozmowy rozbrojeniowe pomiędzy Gorbaczowem i prezydentem Reaganem, które doprowadziły do wycofania z Europy taktycznej broni jądrowej. Polityka „wspólnego domu europejskiego” zainicjowana przez nowe władze na Kremlu dała nowy impuls dyskusjom na temat przyszłego kształtu Europy i przede wszystkim ożywiła nadzieje na pokonanie przeszkód wiodących do zjednoczenia Niemiec. Do końca jednak nie wiedziano, czy warunkiem wstępnym powinno być zjednoczenie Niemiec, czy też należy najpierw zjednoczyć Europę, a następnie dopiero Niemcy. Mówiąc ogólnie coraz częściej podnoszono hasło europeizacji problemu niemieckiego jako warunku wstępnego do zakończenia procesu zimnej wojny w Europie.

Kierownictwo PZPR i rządu polskiego dobrze orientowało się jakie konsekwencje dla PRL mogą wyniknąć z szerokiej międzynarodowej dyskusji na temat przezwyciężenia podziału Europy. W ocenie partyjnych ekspertów piszących na łamach „Nowych Dróg” czy „Ideologii i Polityki” wiązało się to nierozerwalnie z ,polityczno-terytorialnym rewizjonizmem RFN”, a jej głównym zadaniem było stworzenie „psychologicznych przesłanek wokół zjednoczenia Niemiec i odrodzenia mocarstwa wielkoniemieckiego" (Rychłowski, 1986: 166).

Brak poważniejszych efektów w polityce reform gospodarczych, rzutujący na i tak już słabą pozycję międzynarodową PRL, i nie najlepsza kondycja samej partii powodowały, że w latach 1986-1989 jej przywódcom pozostały w ręku praktycznie jedynie ar- 
gumenty uznawania istniejących „realiów” i „geopolityki”, mających uzasadnić dalsze sprawowanie władzy przez PZPR. W wystapieniach przedstawicieli elit partyjnych, obiegu informacyjno-propagandowym coraz częściej pojawiać się zaczął wątek wiążący elementarne bezpieczeństwo Polski z zachowaniem wszystkich istniejących granic. Udzielając wywiadu tygodnikowi „Stern” z okazji 15-lecia układu RFN-PRL z 1970 r., generał W. Jaruzelski apelował do RFN i państw zachodnich o ,ugruntowanie realizmu". Pod tym pojęciem rozumiał rezygnację przez RFN z polityki zjednoczeniowej i podtrzymywania fikcji prawnej o istnieniu Rzeszy Niemieckiej w granicach z 1937 r. (W stosunkach, 1986).

Obrona jałtańsko-poczdamskiego porządku stała się naczelną dewizą propagandy partyjnej. W założeniach i praktyce politycznej taka argumentacja była ostatnią linią obrony racji stanu PRL. Jednakże przemiany na wschodzie i „nowe myślenie” M. Gorbaczowa rzucały wyzwanie skostniałym politykom obozu socjalistycznego i zmuszały ich do przewartościowania opinii o starych wrogach i niewzruszonych podziałach ideologicznych. Liderzy PZPR byli świadomi, że nagminne na doraźny użytek posługiwanie się amerykańskim ,imperializmem” i przede wszystkim „zachodnioniemieckim rewizjonizmem" zaczynało trafiać w pustkę i nie wywoływać spodziewanego rezonansu społecznego. W kreowaniu polityki zagranicznej, zwłaszcza wobec RFN w latach 1987-1989, zdecydowanie na czoło wysunęła się frakcja liberalna w PZPR skupiona wokół późniejszego premiera Mieczysława F. Rakowskiego. Była ona świadoma, że dalsze okopywanie się w antyrewizjonistycznym i antyamerykańskim szańcu trąci anachronizmem i przynosi szkody Polsce Ludowej. Postulowała uregulowanie wszystkich spornych spraw z Niemcami i większe otwarcie Polski na Zachód (Krzemiński, 1988).

Wspierając politykę M. Gorbaczowa i dążąc do podniesienia słabej pozycji Polski na arenie międzynarodowej na II Kongresie Patriotycznego Ruchu Odrodzenia Narodowego (PRON) w Warszawie 8-10 maja 1986 r. generał W. Jaruzelski zapowiedział wystapienie z nowym planem zmniejszenia zbrojeń i zwiększenia zaufania w Europie Środkowej. Miało to nastąpić poprzez stopniowe rozrzedzanie potencjału jądrowego i konwencjonalnych środków walki w regionie rozgraniczającym przeciwstawne sojusze wojskowo-polityczne. Jego propozycja określona mianem planu Jaruzelskiego służyć miała obniżeniu poziomu konfrontacji militarnej i dotyczyć strefy obejmującej terytoria dziewięciu państw: NRD, Czechosłowacji, Węgier, Polski, RFN, Belgii, Holandii, Luksemburga i Danii. W dalszej przyszłości możliwe było objęcie nią obszaru całej Europy, od Atlantyku po Ural. Plan ten zawierał cztery zasadnicze punkty:

- stopniowe wycofywanie i/lub redukcja wspólnie uzgodnionych operacyjnych i taktycznych rodzajów uzbrojenia atomowego; nowością było objęcie redukcją rakiet jądrowych krótkiego zasięgu (do $500 \mathrm{~km}$ );

- zmniejszenie ilości trzech najbardziej niebezpiecznych rodzajów broni konwencjonalnej, tj. broni: o największej sile rażenia, o największej precyzji rażenia oraz służących do prowadzenia operacji zaczepnych w tym nagłej agresji;

- włączenie do dialogu rozbrojeniowego i objęcie budową zaufania doktryn militarnych;

- ciagłe poszukiwanie i uwzględnianie nowych środków bezpieczeństwa i budowy zaufania oraz mechanizmów ścisłej weryfikacji przestrzegania podjętych zobowiązań.

12 maja 1987 r. minister spraw zagranicznych Marian Orzechowski zaprezentował plan na posiedzeniu plenarnym wiedeńskiego spotkania, będącego kontynuacją proce- 
su KBWE. 17 lipca 1987 r. memorandum rządu PRL w sprawie zmniejszenia zbrojeń i zwiększenia zaufania w Europie Środkowej zostało doręczone ambasadorom państw wymienionych w planie i wszystkim państwom członkowskim KBWE. Memorandum uwzględniało sugestie grupy roboczej PZPR i zachodnioniemieckiej SPD, która zaproponowała powołanie do życia Europejskiej Rady Budowy Zaufania, mającej działać obok struktur KBWE, przygotować opracowania analityczne, składać nowe propozycje budowy środków zaufania i przedkładać je na dwóch corocznych sesjach (Koszel, 1989: 100-106).

Plan Jaruzelskiego w dużym stopniu był propagandowym zabiegiem dobrze wpisującym się w logikę działań M. Gorbaczowa powstrzymania zabójczego dla ZSRR wyścigu zbrojeń i pozyskania sobie zachodniej opinii publicznej wizją „wspólnego domu europejskiego". Był to jednocześnie ostatni akord polityki zagranicznej Polski Ludowej w okresie zimnowojennym. W końcu lat 80 . XX w. nową wizję ułożenia stosunków z państwami zachodnimi prezentowała opozycja skupiona wokół „Solidarności" i katolickich intelektualistów i to ona zaczęła nadawać ton debacie publicznej. Zapoczątkowana została dyskusja na temat przezwyciężenia podziału Europy i Niemiec oraz miejsca Polski w jednoczącej się pozimnowojennej Europie. Wybory parlamentarne 4 czerwca $1989 \mathrm{r}$. wyniosły do władzy solidarnościową opozycję. 12 września 1989 r. sformowany został rząd Tadeusza Mazowieckiego, który miał zupełnie odmienną koncepcję rozwoju stosunków z sąsiadami zza ,żelaznej kurtyny”. Główne kierunki polityki zagranicznej sprowadzały się do uzyskania członkostwa w NATO i Wspólnocie Europejskiej oraz pokojowego, dobrosąsiedzkiego ułożenia stosunków ze wszystkimi sąsiadami. W 1991 r. doszło do rozwiązania RWPG i Układu Warszawskiego. Dekompozycja bloku wschodniego i tym samym definitywny kres zimnej wojny zakończył rozpad Związku Radzieckiego w początkach grudnia $1991 \mathrm{r}$.

\section{Bibliografia}

Bingen D. (1997), Polska polityka rzqdu bońskiego od Adenauera do Kohla 1949-1991, Kraków.

Borodziej W. (1990), Od Poczdamu do Szklarskiej Poręby. Polska w stosunkach międzynarodowych 1945-1947, Warszawa.

Czubiński A. (1997), Europa dwudziestego wieku. Zarys historii politycznej, Poznań.

Czubiński A. (1998), Polska i Polacy po II wojnie światowej (1945-1989), Poznań.

Dokumenty i materiaty do historii stosunków polsko-radzieckich (1987), Warszawa, t. 11.

Eisler J. (2008), ,,Polskie miesiace” czyli kryzys (y) w PRL, Warszawa, http://file://C:/Users/Gabinet/Downloads/Jerzy_Eisler_Polskie_Miesiace.pdf (4.04.2015).

Gajdziński P. (2014), Gierek. Człowiek z węgla, Poznań.

Gierek i Jaroszewicz na Kremlu. Protokót z rozmowy Edwarda Gierka z Leonidem Breżniewem w Moskwie, 5 stycznia 1971 (1991), „Polityka”, 9.11.1991.

Gomułka W. (1984), O problemie niemieckim. Artykuły i przemówienia, Warszawa.

Góralski W. M., Barcz J. (1987), Dylematy polityki wschodniej RFN 1982-1985, Warszawa.

Karwat J. (2007), Amerykańsko-radziecka rywalizacja wojskowa w okresie prezydentury Ronalda Reagana, w: Zimna wojna (1946-1989) i jej konsekwencje dla tadu międzynarodowego, (red.) B. Koszel, S. Wojciechowski, Poznań. 
Kemp-Welch A. (2009), Poland under Communism: A cold War History, Cambridge.

Kersten K. (1993), Narodziny systemu władzy: Polska 1943-1948, Warszawa.

Koszel B. (1989), Vom Rapacki Plan zum Jaruzelski Plan. Die polnische Sicherheitspolitik nach dem Zweiten Weltkrieg, „Interanationale Studien. Leipziger Hefte zur Friedensforschung”, No. 4.

Koszel B. (1992), Polityka PRL wobec RFN w latach 1981-1989, w: Polska i Europa XIX-XX wieku. Studia historyczno-politologiczne, (red.) J. Kiwerska, B. Koszel, D. Matelski, Poznań.

Koszel B. (1996), Problem Ziem zachodnich i Pólnocnych Polski w polityce międzynarodowej w latach 1945-1990, w: Pomorze - trudna ojczyzna, (red.) A. Sakson, Poznań.

Koszel B. (2007), Wplyw zimnej wojny na procesy integracyjne w Europie po II wojnie światowej, w: Zimna wojna (1946-1989) i jej konsekwencje dla ładu międzynarodowego, (red.) B. Koszel, S. Wojciechowski, Poznań.

Koszel B. (1999), Die Außenpolitik der Volkrepublik Polen gegenüber der Bundesrepublik Deutschland 1949-1989, w: J. Barbian, M. Zybura, Erlebte Nachbarschaft. Aspekte der deutsch-polnischen Beziehungen im 20. Jahrhundert, Wiesbaden.

Koszel B. (2007), Polish-German Relations and European Security, w: Poland-Germany 1945-2007. From Confrontation to Cooperation and Partnership in Europe. Studies and Documents, (ed.) W. M. Góralski, Warsaw.

Kralewski W. (1983), Der Rapacki - Plan: Bemühungen zur Schaffung einer atomwaffenfreien und rüstungsbegrenzten Zone in Europa, Tübingen.

Krasuski J. (1987), Historia RFN, Warszawa.

Krzemiński A. (1988), Musimy się poruszać, „Polityka”, 30.01.1988.

Liczmański R. (1989), Adam Rapacki. Zarys biograficzny, Warszawa.

Łoś R. (2004), Republika Federalna Niemiec wobec Planu Adama Rapackiego, „Przegląd Zachodni”, nr 1.

Łoś-Nowak T. (1989), Plan Rapackiego - geneza i ewolucja założeń, „Sprawy Międzynarodowe”, nr 9.

Mac Eachin D. J. (2002), U.S. Intelligence and the Confrontation in Poland 1980-1981, Kindle Edition.

Małcużyński K. (1965), Plan Gomułka. Le gel des armaments nuceléaires en Europe Centrale, Warszawa.

Ozinga J. R. (1989), The Rapacki Plan: The 1957 Proposal to Denuclearize Central Europe, and an Analysis of Its Rejection, Jefferson, N.C.

Paczkowski A. (1993), Zdobycie władzy 1945-1947, Warszawa.

Plan Jaruzelskiego" jako polska inicjatywa pokojowa (1987), Stowarzyszenie Pax: Ośrodek Spraw Międzynarodowych, Warszawa.

Rotfeld D. A. (1984), Bezpieczeństwo Polski a bezpieczeństwo Europy, „Sprawy Międzynarodowe”, nr 7-8.

Rolicki J. (1990), Edward Gierek: przerwana dekada, Warszawa.

Rychłowski B. (1986), Poszanowanie ładu polityczno-terytorialnego fundamentem pokoju w Europie, ,Nowe Drogi”, $\mathrm{nr} 5$.

Schwarz H.-P. (1983), Die Ära Adenauer 1949-1963, w: Die Geschichte der Bundesrepublik Deutschland, (Hrsg.) K.-D. Bracher, Th. Eschenberg, J. Fest, Wiesbaden-Mannheim.

Skobelski R. (2010), Polityka PRL wobec państw socjalistycznych w latach 1956-1970. Wspótpraca - napięcia - konflikty, Poznań.

Skórzyński J. (2012), Siła bezsilnych. Historia Komitetu Obrony Robotników, Warszawa. 
Stefanowicz J. (1980), Europa powojenna, Warszawa.

Thiem J. (1989), Für eine chemiefreie Zone in Europa, „Internationale Studien. Leipziger Hefte zur Friedensforschung", No. 4.

Tomala M. (1987), Warszawa-Berlin-Bonn (1944-1980), Szczecin.

W stosunkach pomiędzy Polskq a RFN liczq sięfakty, a nie deklaracje. Wywiad I Sekretarza KC PZPR, przewodniczacego rady państwa, gen. armii Wojciecha Jaruzelskiego dla tygodnika ,, Stern” (1986), „Trybuna Ludu”, 6.06.1986.

Zięba R. (1989), Polska w stosunkach międzynarodowych 1945-1989, Torun.

\title{
STRESZCZENIE
}

System jałtańsko-poczdamski powstały w wyniku II wojny światowej włączył Polskę w orbitę wpływów Związku Radzieckiego. Została ona uzależniona gospodarczo (RWPG) i militarno-politycznie (Układ Warszawski) od wschodniego sąsiada. Podejmowane próby zbyt samodzielnego wzmocnienia bezpieczeństwa Polski (plan Rapackiego, plan Gomułki, układ grudniowy w 1970 r. z RFN) kończyły się niepowodzeniem. Stan wojenny w 1981 r. pogłębił izolację międzynarodową Polski i dodatkowo uzależnił ją od Moskwy. Odejście od konfrontacji międzyblokowej w końcu lat 80. spowodowało podpisanie traktatu granicznego w Niemcami i reorientację Polski na współpracę ze światem zachodnim.

\section{POLAND'S SECURITY DURING THE COLD WAR}

\begin{abstract}
Yalta-Potsdam system emerged from World War II turned Poland into the orbit of the Soviet Union. It was economically dependent (CMEA) and the military-political (the Warsaw Pact) from the eastern neighbor. Taken attempts too independent to strengthen Polish security (Rapacki Plan, Gomulka Plan, Polish-German Agreement of December 1970) ended in failure. Martial law in 1981, the international isolation deepened in Polish and also became addicted to from Moscow. Moving away from confrontation between East and West at the end of the years 80. resulted in the signing of the border treaty with Germany (1990) and the reorientation of the Polish on the cooperation with the Western World.
\end{abstract}

